\title{
Valsts un pašvaldỉbas kompetence sabiedriskās kārtības nodrošināšanā publiskos pasākumos
}

\author{
Kristine Kuznecova \\ Rīgas Stradiña universitāte, Juridiskā fakultāte, Latvija \\ Valsts policijas koledža, Latvija
}

\section{Kopsavilkums}

Arvien aktuālāki kḷūst jautājumi par valsts un pašvaldības institūciju kompetenci sabiedriskās kārtības un drošības garantēšanā publisku pasākumu laikā. Tiesību aizsardzības iestādēm viens no svarīgākajiem uzdevumiem ir sabiedriskās kārtības un drošības garantēšana šo pasākumu norises vietās. Lai arī būtiska loma tās nodrošināšanā ir atvēlēta pašvaldību institūcijām (pašvaldības policija šobrīd ir viens no nozīmīgākajiem Valsts policijas sadarbības partneriem policijas funkciju pildīšanā), praksē novērojamas vairākas problēmas. Pirmkārt, vai valsts un pašvaldības policijas iestādēm ir pietiekami materiāltehniskie un cilvēkresursi, lai garantētu sabiedrisko kārtỉbu liela mēroga (arī paaugstināta riska) publiskos pasākumos? Otrkārt, vai šo iestāžu darbinieki publisku pasākumu laikā izmanto samērīgus tiesiskos līdzekḷus, lai vērstos pret sabiedriskās kārtības pārkāpējiem?

Atslēgvārdi: publiski pasākumi, sabiedriskās kārtības un drošības garantēšana.

\section{Raksta mērḳis}

Raksta mērḳis ir izpētìt valsts un pašvaldības iestāžu kompetences apjomu, garantējot sabiedrisko kārtību publisku pasākumu laikā. Termini "sabiedriskā kārtība", "sabiedriska vieta", "publisks pasākums" šajā rakstā saturiski sīkāk netiks analizēti. Rakstā valsts un pašvaldības kompetence, garantējot sabiedrisko kārtību publisku pasākumu laikā, tiks skatīta atbilstīgi Publisku izklaides un svētku pasākumu drošības likumā noteiktajam "publiskas vietas" un "publiska pasākuma" definējumam [3, 1. pants]. Šajā publikācijā autore vēlas noškirt likumā "Par sapulcēm, gājieniem un piketiem" noteiktās un valsts garantētās un aizsargātās miermīlīgās pulcēšanās brīivibas izpausmes - sapulces, gājienus un piketus. 


\section{Rezultāti}

Demokrātijas stabilitātes jeb izmaiṇu un stabilitātes paradoksa problēmu var uzskatīt par centrālo jaunu politisko sistēmu veidošanās gadījumos. G. Ozolzīle norāda $[15,41]$, ka ar jēdzienu "jauna politiska sistēma" ir jāsaprot tāda sistēma, kas atrodas veidošanās (aut. piezīme - pilnveidošanās) procesā, un par tādu šobrīd var uzskatīt arī Latvijas sistēmu. Demokrātijas stabilitātes jēdziens politikas zinātnē tiek izmantots bieži, bet jāatzīst, ka tā aprises ir izplūdušas. Lielākoties tas tiek saprasts visai šauri un mehāniski - kā valdību stabilitāte. Dažās situācijās demokrātijas stabilitātes jēdziens tiek skatīts plaši un nekonkrēti - kā visas politiskās sistēmas stabilitāte. Jāpiekrīt A. Lijphartam (A. Lijphart) [13, 217], kas demokrātisko stabilitāti iztirzā plašākā nozīmē un ietver tajā arī pilsonisko kārtību un drošỉbu, zemu vardarbības līmeni, valsts pārvaldes sistēmas leg̣itimitāti un efektivitāti.

Lai gan Latvija ir iestājusies Eiropas Savienībā, iekḷāvusies Šengenas zonā un vērojama ekonomiskā cikliskuma augšupeja pēdējos gados [8, 3], pēc autores domām, Latvijā joprojām pastāv virkne nopietnu šḳēršlu demokrātiskās stabilitātes pastāvēšanai. Minētais vistiešākajā veidā ietekmē arī sabiedriskās kārtības un drošības garantēšanas jomu publisku pasākumu laikā. Arvien biežāk Latvijas pilsētās, novados un pagastos tiek rīkoti publiskie pasākumi, t. sk. sporta pasākumi, kuros vienuviet pulcējas liels cilvēku skaits ar dažādu sociālās spriedzes līmeni. Var gadīties, ka dažādu apstākḷu ietekmē publisks pasākums no sākotnēji miermīlīga var pārvērsties par enerǵijas avotu agresīvu cilvēku pūlim, kura darbība pāraug vardarbībā, demolēšanā, mantas bojāšanā, sabiedrībā pieṇemto uzvedības noteikumu un tiesību normu ignorēšanā. Šādas situācijas ne tikai negatīvi ietekmē sabiedrības drošỉbu kopumā, bet, iespējams, pat rada apdraudējumu valsts drošībai tajos gadījumos, ja izcel̦as plaša mēroga masu nekārtības (nemieri) dažādu izklaides pasākumu vai sporta spẹlı laikā, vai masu nekārtības ir saistìtas ar šo pasākumu norisi. Tādēl vēlreiz jāuzsver nepieciešamība policijas iestādēm būt gatavām novērst un pārtraukt šādas situācijas, izmantojot visus pieejamos tiesiskos lìdzekḷus.

Demokrātijas stabilitātes pastāvēšanas process, kā norādīts iepriekš, nav iedomājams bez centieniem nodrošināt likumību un tiesību aizsardzību no valsts puses. Tāpat tas nav iedomājams bez iedzīvotāju apzinātas nepieciešamības pildīt pienākumus. Viens no nepieciešamākajiem un pirmajiem valsts uzdevumiem ir kārtības un drošības garantēšana valstī, personu un vinu likumīgo darbību aizsardzība pret varbūtējiem draudiem un uzbrukumiem. Raksta tēmas ietvaros, neapšaubāmi, autores interesi izraisa viena no svarīgākajām valsts funkcijām - policejiskā funkcija - sabiedriskās kārtības un sabiedrības drošības garantēšana valstī. Atbilstīgi likuma "Par policiju" 1.-3. pantā minētajam, policija ir apbruṇota, militarizēta valsts vai pašvaldības institūcija, tātad valsts pārvaldes institūcija, kuras uzdevums ir nodrošināt sabiedrisko kārtību un mieru, sekmēt sabiedrības veselību, drošỉbu, tikumību, kā arī nodrošināt noziegumu novēršanu un atklāšanu, vainīgo personu saukšanu pie atbildības. [2] Papildus jānorāda, 
ka policijas uzdevumus sabiedriskās kārtības un drošības garantēšanā nedrīkst skatīt atrauti no diviem aspektiem. Pirmkārt, policijas darbības prioritātes nosaka sabiedrība, tādēl policijas uzdevumiem ir jābūt noteiktiem atbilstoši sabiedrības interesēm. Otrkārt, policijas darbībai ir jābūt vērstai uz valsts un pašvaldỉbas institūciju lēmumu realizāciju.

Policijas darbība mūsdienu demokrātiskā sabiedrībā tiek vērtēta atbilstoši tam, cik efektīvi tiek uzturēta sabiedrības drošība, vienlaikus aizsargājot personu tiesības un brīvības. To garantēšana ir universāls policijas pozitīvās lomas vērtēšanas kritērijs visās sabiedrisko attiecību jomās. Tiesību aizsardzības iestāžu un citu par sabiedrisko kārtību atbildīgo iestāžu pienākums ir nodrošināt Satversmē noteiktās konstitucionālās tiesības un brīvības: "Valsts atzīst un aizsargā cilvēka pamattiesības saskaṇā ar šo Satversmi, likumiem un Latvijai saistošiem starptautiskajiem līgumiem" [1, 89. pants]. Minētais valsts uzdevums kḷūst krietni sarežgitīāks, ja publisku pasākumu norises vietās vienkopus pulcējas liels cilvēku skaits ar mērḳi realizēt savas likumā noteiktās tiesības un brīvības, piemēram, realizēt Satversmes 100. pantā noteikto, ka "ikvienam ir tiesības uz vārda brīivibu, kas ietver tiesības brīvi iegūt, paturēt un izplatìt informāciju, paust savus uzskatus" $[1,100$. pants $]$.

Valsts politiku noziedzības apkarošanas un sabiedriskās kārtības un drošības aizsardzībā, kā arī personu tiesību un likumīgo interešu aizsardzībā Latvijā atbilstīgi kompetencei issteno Valsts policija $[6,1$. punkts]. Policijas darbinieka pamatpienākumus sabiedriskās kārtības nodrošināšanas jomā noteic likuma "Par policiju" 10. pants: “. nodrošināt kārtību uz celiiem, ielās, laukumos, parkos, sabiedriskā transporta līdzekḷos, lidostās, ostās, stacijās un citās publiskās vietās, lai garantētu personu un sabiedrības drošību; novērst un pārtraukt administratīvos pārkāpumus, noskaidrot vainīgos, savas kompetences ietvaros sastādìt protokolus .." [2, 10. punkts]. Valsts policijā pēc pastāvošā iekšējā funkcionālā sadalỉjuma kriminālpolicijas struktūrvienības nodrošina noziedzìgu nodarījumu atklāšanu, novēršanu un noziedzīgus nodarījumus izdarījušu personu meklēšanu $[12,155]$, savukārt sabiedriskās kārtības nodrošināšana, satiksmes uzraudzība un, neapšaubāmi, klasiskajā izpratnē prevencija (lat. pravevenire aizsteigties priekšā) ir kārtības policijas prerogatīva.

Ar Valsts policijas 2010. gada 22. februāra noteikumiem Nr. 5 "Dienesta pienākumu izpildes organizācija un kontrole sabiedriskās kārtības nodrošināšanas un satiksmes uzraudzības jomā" noteikts, ka sabiedrisko kārtību un satiksmes uzraudzỉbu - atbilstīgi savai kompetencei - nodrošina Valsts policijas kārtỉbas policijas struktūrvienības. Tās ir patruḷdienests, satiksmes uzraudzības struktūrvienības, kārtības policijas inspektori (iecirkṇa inspektori, nepilngadīgo lietu inspektori), operatīvās vadības struktūrvienības, konvoja dienests, aț̣auju sistēma un objektu apsardze. Šìs ir kārtības policijas jomas un pamatpienākumi, kas skar sabiedriskās kārtības nodrošināšanu, likumpārkāpumu novēršanu un atklāšanu. To galvenais uzdevums ir, veicot sabiedriskās kārtības nodrošināšanu vai satiksmes uzraudzību, panākt likumpārkāpumu novēršanu, kā arī satiksmes negadijumu un tajos cietušo personu skaita samazināšanos. [7] 
Saskaṇā ar Publisku izklaides un svētku pasākumu drošỉbas likumā noteikto par kārtỉbas uzturēšanu publisku pasākumu laikā ir atbildīga Valsts policija vai pašvaldības policija, Zemessardze, kā arī juridiskā persona, kurai izsniegta licence apsardzes darbỉbas veikšanai un ar kuru pasākuma organizators ir noslēdzis līgumu par sabiedriskās kārtības un drošības, kā arī ugunsdrošības prasību izpildi pasākuma laikā. Uzdevumu izpildi sabiedriskās kārtības nodrošināšanas, likumpārkāpumu novēršanas un satiksmes uzraudzības jomā publisku pasākumu laikā primāri nodrošina reǵionālās pārvaldes kārtības policijas patruḷpolicijas amatpersonas, to skaitā arī tās amatpersonas, kuras dienesta pienākumu izpildi veic satiksmes uzraudzības jomā.

Vērtējot Valsts policijas personālresursus, to spēju garantēt kārtību publisku pasākumu laikā, jāsecina, ka dažās situācijās resursi ir ierobežoti. Uzdevumu izpildes kvalitāti sabiedriskās kārtības garantēšanā publisku pasākumu laikā būtiski kavē neaizpildītās vakances: šobrīd Valsts policijā ir apmēram 1670 patrulpolicijas un satiksmes uzraudzības amatpersonas, bet faktiski dienesta pienākumu izpildē ir iesaistitas 420 amatpersonas, un vakanto amatu vietu skaits ir 240. [9] Sniedzot atbalsta funkcijas sabiedriskās kārtības nodrošināšanā masu pasākumos ārkārtas un krīzes situācijās, dienesta pienākumu izpildē ir iesaistītas apmēram 150 patruḷpolicijas Speciālo uzdevumu bataljona amatpersonas. N̦emot vērā, ka lielākoties visas kārtības policijas struktūrvienības ir ievērojami nenokomplektētas, realitātē jāsaskaras ar situācijām, ka patrulppolicijas amatpersonas tiek iesaistītas citu uzdevumu izpildē, nevis savu tiešo pamatfunkciju veikšanā, proti, sabiedriskās kārtības nodrošināšanā.

Valsts policijas darbību sabiedriskās kārtības un drošības garantēšanā publisku pasākumu laikā var iedalīt trīs posmos: sagatavošanās, izpilde un noslēgums.

Pirmajā, sagatavošanās posmā, Valsts policijas kārtības policijas priekšnieks, saṇemot uzdevumu par sabiedriskās kārtības nodrošināšanu publiska pasākuma laikā, novērtē situāciju, iegūstot (pieprasot) informāciju par pasākuma saturu, tā dalībniekiem, nolūkiem un norisi, tad viņš noteiktā kārtībā par pasākuma pieteikumu informē Valsts policijas Galvenās kārtības policijas pārvaldi. Tāpat kārtības policijas priekšnieks organizē un veic apdraudējuma risku analīzi (mērḳtiecīga papildu informācijas ieguve par iespējamiem sabiedriskās kārtības pārkāpumiem konkrētajā pasākumā) un organizē plāna izstrādi par sabiedriskas kārtības nodrošināšanu, norīkojot par plāna izstrādi atbildīgo amatpersonu un personīgi kontrolējot izstrādes gaitu. Sagatavošanās posmā tiek organizēti personālsastāva un tehnisko lìdzekḷu sagatavošanas pasākumi. Lai darbu sekmīgi veiktu, notiek teritorijas un objektu apsekošana kopā ar organizatoriem. Tāpat notiek norīkojumā nosūtîto darbinieku un amatpersonu dienesta instruktāža, tiek organizēta visu atbildīgo institūciju un dienestu sadarbība. Bieži vien grandiozu un plašu publisku pasākumu laikā tiek izveidoti operatĩvie vadības štābi, kuri nepieciešami visu darbību koordinēšanai un realizācijai.

Izpildes posms aptver laiku no sabiedriskās kārtības nodrošināšanā iesaistīto spēku pienākumu izpildes sākuma un turpinās līdz tā pabeigšanai. Šajā posmā tiek organizēta dienestu un norīkojumu vadība, noteikti transporta un gājēju kustības 
ierobežojumi, nodrošināts caurlaižu režīms kontroles posteņos. Policijas galvenais uzdevums publiska pasākuma laikā, saskaņā ar Pārvaldes priekšnieka apstiprinātu plānu, ir nodrošināt sabiedrisko drošîbu un kārtību publiskā pasākumā. Līdz ar to policijai ir tiesības aizliegt ienest publisko pasākumu norises vietās jebkādus dzērienus stikla vai citā plīstošã iepakojumā, neielaist pasākuma norises vietā iereibušas personas, kā arī personas bez biḷetēm, ieejas kartēm vai caurlaidēm, par sīkiem pārkāpumiem brīdināt pārkāpumu izdarītājus, neizraisot konflikta situācijas. Tāpat policijai ir tiesības aizturēt pasākuma laikā noklīdušus bērnus, ja iespējams, noskaidrot vinu vārdu, uzvārdu un organizēt bērnu nodošanu attiecīgām amatpersonām, veikt pasākumus, lai sabiedriskās kārtības grupveida pārkāpumus pārtrauktu jau sākuma stadijā, aizturēt nekārtību izraisītājus un aktīvos dalībniekus, neizraisot situācijas saasināšanos. Šajā posmā vadība kontrolē rīkojumu un komandu izpildi, kā arī norit visu atbildīgo iestāžu cieša sadarbība.

Noslēguma posms sākas ar pasākuma pabeigšanas brīdi un beidzas, kad pasākuma apmeklētāji izklīst. Šajā posmā tiek atcelti ieviestie ierobežojumi, pilnā apjomā atjaunots pārtrauktais transporta un dažu uzṇēmumu darbs. Pasākuma noslēguma posmā policijas darbinieka pienākums ir brīdināt dalībniekus/skatītājus nedrūzmēties pie galvenajām izejas vietām un norādìt papildu izejas. Pēc pasākuma noslēgšanas dienesta pienākumu izpildi drīkst beigt tikai ar priekšnieka (komandiera) aț̣auju, ja tas nav atrunāts citādāk. Noslēguma posmā tiek veikts rezultātu apkopojums un dots kopējais vērtējums. Nopietnu pārkāpumu gadỉjumos, kas varētu ietekmēt sabiedrības drošību kopumā citu publisku pasākumu laikā, tiek sagatavota informācija un nosūtīta vietējai pašvaldībai vai pasākumu organizatoriem. [14, 59]

Analizējot policijas norīkojumu vai faktisko sabiedriskās kārtības nodrošināšanā iesaistīto policijas darbinieku pienākumus sagatavošanās, izpildes un noslēguma posmos, jāsecina, ka pienākumu izpilde sākas ar brīdi, kad tiek saṇemts uzdevums. Plānā par sabiedriskās kārtības un ceḷu satiksmes drošības garantēšanu ir jāparedz pasākuma nodrošināšanas galvenie uzdevumi, publiskā pasākuma vieta, laiks un norises kārtība, policijas darbinieku pienākumi pasākuma laikā, par uzdevumu izpildi atbildīgās personas, sakaru organizācija, ekipējums, instruktāžas un dienesta sākuma laiks. Policijas darbinieku uzdevumi publisku pasākumu laikā, kā tika norādīts iepriekš, ir nodrošināt publisko pasākumu dalïbniekiem noteikto uzvedības normu stingru ievērošanu, sniegt atbalstu un palīdzību valsts un pašvaldību iestādēm, pasākumu organizētājiem, lai sekmētu pasākumu norisi, laikus novērst un atklāt noziedzīgus nodarījumus, sabiedriskās kārtības noteikumu pārkāpumus publisku pasākumu norises vietās. Policijas darbinieks ir tiesīgs dot saistošus norādījumus pasākuma organizatoram, vadītājam, dalībniekiem un kārtības uzturētājiem, lai nodrošinātu sabiedrisko kārtību un nepiel̦autu sabiedriskās kārtības pārkāpumus.

Aplūkojot ārvalstu policijas iestāžu pieredzi sabiedriskās kārtības garantēšanā publisku pasākumu laikā, autores interesi piesaistīja Nīderlandes policijas prakse. Lai nodrošinātu sabiedrisko kārtību publiskos pasākumos, Nīderlandes policija darba 
pamatā izvirzījusi vairākus principus: aizsargāt indivīda tiesības uz vārda brīvību un pulcēšanos, cieši kontaktēt un uzturēt dialogu ar sabiedrību, panākt sabiedrības uzticēšanos valsts pārvaldei un policijai, gādāt par policijas darbinieku profesionalitāti, policijas darbības nepārtrauktību, vardarbības draudu novēršanu. [17] Lai nodrošinātu šeit minēto principu realizāciju, Nīderlandes policija ir izveidojusi Miera vienību (Peace Unit), kuras uzdevums ir veikt laikus un nepārtrauktu komunikāciju ar publiska pasākuma dalībniekiem, uzturēt kontaktus ar pasākuma riska grupām, novērst vardarbības draudus. [18, 14] Miera vienības darbinieki publiska pasākuma laikā pārvietojas kājām, viṇi uzrunā publiska pasākuma dalībniekus un ir sasniedzami. Darbinieku izskats ir neuzkrītošs, viṇi nav apbruṇoti un nav tērpušies speciālajā ekipējumā, tādā veidā neradot papildu satraukumu vai agresiju pasākuma dalībnieku vidū. Miera vienība visu pasākuma laiku uztur kontaktus ar citām policijas vienībām, maksimāli nodrošinot iespēju izvairīties no sabiedriskās kārtības grupveida pārkāpumiem. Tā tiek salīdzināta ar policijas "acīm un ausīm", bet nepieciešamības gadījumā, kad jānovērš vai jāpārtrauc sabiedriskās kārtības pārkāpumi (vai nekārtības), ir gatava un iesaistās masu nekārtību novēršanas vienība (Squad), kura atrodas netālu.

Šis raksts l̦auj secināt, ka sabiedriskās kārtības un drošības garantēšanas funkcijas publiska pasākuma laikā pamatā īsteno Valsts policija, tomēr jāatzīst, ka būtiska loma procesā ir atvēlēta arī vietējo pašvaldỉbu institūcijām - subjektiem, kas atbildīgi par vietējo iedzīvotāju sociālo un fizisko drošîbu. Saskañā ar likuma "Par pašvaldībām" 15. panta pirmās dal̦as 12. punktu viena no pašvaldību autonomām funkcijām ir dalība sabiedriskās kārtības nodrošināšanā, žūpības un netiklỉbas apkarošanā. Pašvaldībām autonomo funkciju îstenošanā zināmā mērā ir rīcības brīvība. Minētās funkcijas var tikt ìstenotas dažādos veidos un dažādos līmen,os: izveidojot pašvaldỉbas administratīvo komisiju un/vai pašvaldības policiju, izveidojot pašvaldībā sabiedriskās kārtības sargu amatus, pilnvarojot pašvaldības amatpersonas kontrolēt saistošo noteikumu izpildi un piemērot sodus par to pārkāpšanu, sniedzot atbalstu tiesību aizsardzības iestādēm. Šo autonomo funkciju ĩstenošana pašvaldībām vienlaikus piešḳir ne tikai lēmumu iniciatīvas tiesības, lēmumu pieñemšanas un ìstenošanas brīvỉbu, bet arī noteiktu atbildỉbu par šo funkciju îstenošanu. Tas nozīmē, ja, piemēram, pašvaldība organizē vai izsniedz atḷaujas rīkot publiskus pasākumus (izklaides sarīkojumus, sporta sacensības), tad tai ir tiesības un arī pienākums iniciēt un patstāvīgi pieṇemt lēmumu par sabiedriskās kārtības nodrošināšanu savā teritorijā to īstenos policija, kuras pārraudzībā ir pašvaldỉbas teritorija, sabiedrisko kārtību nodrošinās pašvaldības izveidota pašvaldības policija vai to veiks privātie apsardzes uzñēmumi. [11, 336]

Likuma "Par policiju" 19. pants noteic, ka pašvaldỉba var izveidot pašvaldỉbas policiju vai Valsts pārvaldes iekārtas likumā noteiktajā kārtībā delegèt uzdevumu izpildi citai pašvaldībai. Tiesību norma, kas ḷauj pašvaldībām izveidot pašvaldības policiju, pieškirir tiesības, bet neuzliek pienākumu veidot savā administratīvajā teritorijā pašvaldỉbas policiju. 
Atbilstīgi likuma "Par policiju" 19. pantā noteiktajam, pašvaldības policijas darbinieku pienākumos ietilpst "likumpārkāpumu profilakse, kontrole par to, kā tiek izpildīti pašvaldību apstiprinātie noteikumi, par kuru pārkāpšanu paredzēta administratĩvā atbildība, Valsts policijas un Drošỉbas policijas atbalstî̌sana sabiedrības drošības garantēšanā un noziedzības apkarošanā” [2, 19. pants]. Pašvaldības policijas lomu sabiedriskās kārtības nodrošināšanā uzskatāmi atspoguḷo Ventspils pašvaldības policijas darbības rezultāti. Ventspils pilsētas pašvaldības policija tika izveidota 1992. gada 26. oktobrī saskañā ar likuma "Par policiju" 19. pantu un pamatojoties uz Ventspils pilsētas Tautas deputātu padomes valdes lēmumu. Ventspils pašvaldības policija gadu gaitā ir uzṇēmusies arvien vairāk funkciju, kuru izpildi Valsts policija resursu trūkumu dēl nespēj nodrošināt vai ir pārtraukusi pildīt. Pašvaldības policijā strādā 60 pašvaldības policijas darbinieki. Tikai pašvaldības policijai Ventspils administratīvajā teritorijā ir patruḷdienests (3-4 patruḷu grupas diennaktī) ar patrulēšanas intensitāti vienai mobilajai patrulas grupai $300-400 \mathrm{~km}$ diennaktī. Pašvaldības policija apkalpo gandrīz visus pilsētas iedzīvotāju izsaukumus (vidēji 4500 izsaukumu gadā). Daḷa Valsts policijā saṇemto izsaukumu tiek pāradresēti pašvaldības policijai. Ventspils pašvaldības policija nodrošina sabiedrisko kārtību sporta, kultūras un citos pasākumos (vidēji gadā ap 150). Valsts policija šajos sarīkojumos piedalās tikai cel̦u satiksmes ierobežošanā. Pašvaldības policija ir atbildīga par pilsētas pludmales glābšanas dienesta darba organizēšanu peldsezonas laikā, to 2012. gadā nodrošināja 10 glābēji, kuru rīcībā ir iegādāts atbilstīgs moderns ekipējums (glābšanas motorlaiva u. c.). [19]

Sabiedriskās kārtības un drošỉbas joma publisku pasākumu laikā nenoliedzami var būt saistīta ar dažādām ārkārtas situācijām stihisku nelaimju, ugunsgrēku, rūpniecisko avāriju, katastrofu un epidēmiju gadījumā. Sabiedriskās kārtības un drošības kopējais elements ir fokusēšanās uz indivīdu personisko (fizisko) drošību, aizsardzību no dažādiem apdraudējumiem arī civilās drošības jomā. Būtisks jautājums, kuru autore vēlas iztirzāt, ir Zemessardzes loma sabiedriskās kārtības un drošības garantēšanā publisku pasākumu laikā. N̦emot vērā nemilitāro draudu izteikto dominanci pār militārajiem, zemessargiem ir noteikta l̦oti nozīmīga vieta atbalsta sniegšanā valsts aizsardzības civilajai komponentei. Pamatojoties uz ìpaši izstrādātu tiesisko regulējumu, Zemessardzes speciālisti neitralizē un iznīcina sprādzienbīstamus priekšmetus, sniedz atbalstu Valsts policijai un pašvaldībām civilās aizsardzības plānu (preventīvo, reageēšanas un seku likvidēšanas pasākumu) ìstenošanā, sabiedriskās kārtības un drošības garantēšanā, pazudušu personu meklēšanā, ugunsdzēsības un glābšanas darbos, dabas un tehnogēno katastrofu seku likvidēšanā, kā arī atbalsta Drošîbas policiju, Valsts robežsardzi, Valsts meža dienestu, Valsts vides dienestu un Dabas aizsardzības pārvaldi to uzdevumu izpildē. [4] Lai attīstītu Zemessardzes spējas pilnvērtīgāk sadarboties ar valsts un pašvaldības institūcijām, tiek pilnveidots tiesiskais regulējums un izstrādāts atbilstīgs sadarbības mehānisms, kas iekḷauj ne tikai vienošanos par sadarbības procedūrām un koordināciju, bet arī paredz organizēt speciālu apmācību. [5] 
Par nepieciešamību aktīvāk iesaistīt zemessargus policijas funkciju pildīšanā, kā arī par Zemessardzes darbinieku apmācības sabiedriskās kārtības un drošības nodrošināšanā lietderīgumu tiek diskutēts jau kādu laiku. Vairākkārt izskanējis viedoklis [16], ka varbūt veiksmīgāk būtu veidot sadarbību ar apsardzes komersantiem, nevis Zemessardzi. Kādēl būtu jāapmāca Aizsardzības ministrijas struktūrvienība? Vai, piemēram, tiek diskutēts par policijas palīga institūta nostiprināšanu un palīgu iesaistîšanu sabiedriskās kārtības nodrošināšanā. Autore gan norāda, ka jautājums ir par ārkārtas situācijām un krī̌zu pārvaldīšanu. Zemessardze ir Nacionālo bruṇoto spēku rezerve. Un, piemēram, masu nekārtību gadījumā, ja tiek pārsniegta policijas kapacitāte, ārkārtas situācijā tiek piesaistīti iepriekš apmācīti Zemessardzes spēki, kas ir valsts stratēéiskā rezerve un resursi. Šobrīd ir noslēgti sadarbības līgumi starp Zemessardzi un Valsts policiju, kā arī starp Zemessardzi un pašvaldībām. [10] Jānorāda, ka Zemessardze savas kompetences ietvaros ir un paliek valsts dienests. Ārkārtas gadījumos tā darbojas atbilstīgi savai kompetencei.

\section{Secinājumi}

Policijas kā valsts pārvaldes institūcijas viens no galvenajiem uzdevumiem ir nodrošināt sabiedrisko kārtību un drošîbu publisku pasākumu laikā. Lai arī šobrīd policijas iestādes skar virkne organizatorisko (personālsastāva) un tiesisko problēmu, policijas dienestu uzdevums ir veikt visefektīvākos pasākumus, lai garantētu pasākumu mierīgu norisi. Policijas dienestu rīcības efektivitāti publisku pasākuma laikā nosaka ne tikai spēja ātri reagèèt un novērst sabiedriskās kārtības pārkāpumus, bet arī likumiska un samērīga policijas rīcība pārtraucot sabiedriskās kārtības pārkāpumus. Pašvaldības policijas institūts (arī Zemessardze kā Nacionālo bruṇoto spēku sastāvdaḷa) ir viens no nozīmīgākajiem Valsts policijas sadarbības partneriem policijas funkciju nodrošināšanā. Tas nozīmē, ka paredzot konkrētus sadarbỉbas modeḷus, sadarbības līgumus starp valsts un pašvaldību institūcijām, kā arī tiesībaizsardzības institūcijām savā starpā, būtiski uzlabosies sabiedriskās kārtības nodrošināšanas kvalitāte publiskos pasākumos.

\section{State and Local Government Competence in Guaranteeing Public Safety during Public Events}

\section{Abstract}

Issues affecting the state and local government institution competence in public order and security maintaining in public events is becoming increasingly crucial. One of the most important tasks of the law enforcement agencies is guaranteeing public order and security. Although the crucial role in guaranteeing is devoted to local government 
bodies, where municipal police institute is currently one of the most important partners of the State Police in police powers provision, in practice are turning out a number of problems. First, whether the state and municipal police authorities have sufficient logistical and human resources to ensure public order in large-scale (and sensitive) public events. Second, whether the enforcement officers during public events use proportionate legal means to crack down violators of public order.

Keywords: public events, maintenance of public order and safety.

\section{Literatūra}

1. Latvijas Republikas Satversme. Latvijas Vēstnesis, Nr. 43, 1993. g. 1. jūl., 89. pants.

2. Likums "Par policiju": 1991. g. 4. jūn. Rīga: Ziņotājs, Nr. 37, 1992. g. 24. sept., 1. pants.

3. Publisku izklaides un svētku pasākumu drošības likums: 2005. g. 16. jūn. Latvijas Vēstnesis, Nr. 104 (3262), 2005. g. 6. jūl.

1. pants. Publisks pasākums - fiziskās vai juridiskās personas plānots un organizēts sabiedrībai pieejams svētku, piemiṇas, izklaides, sporta vai atpūtas pasākums publiskā vietā neatkarīgi no īpašuma piederības. Publiska vieta - jebkura vieta, kura neatkarīgi no tās faktiskās izmantošanas vai īpašuma formas kalpo sabiedrības kopējo vajadzību un interešu nodrošināšanai un kura par maksu vai bez maksas ir pieejama ikvienai fiziskajai personai, kas nav attiecīgās vietas īpašnieks, tiesiskais valdītājs, turētājs, algots darbinieks vai cita persona, kuras atrašanās attiecīgajā vietā ir saistīta ar darba pienākumu izpildi, pasākuma organizēšanu vai ir uz uzṇēmuma līguma pamata.

4. 2010. gada 9. oktobra Ministru kabineta noteikumi Nr. 936. "Kārtība, kādā Latvijas Republikas Zemessardze sniedz atbalstu valsts un pašvaldību institūcijām likumpārkāpumu novēršanā, sabiedriskās kārtības un drošības garantēšanā". Latvijas Vēstnesis, Nr. 160 (4352), 2010. g. 8. okt.

5. 2014. gada 7. aprīḷa Ministru kabineta rīkojums Nr. 151 "Par valdības rīcības plānu Deklarācijas par Laimdotas Straujumas vadītā Ministru kabineta iecerēto darbību īstenošanai”. Latvijas Vèstnesis, Nr. 71 (5131), 2014. g. 9. apr., 121. punkts.

6. 2005. gada 18. janvāra Ministru kabineta noteikumi Nr. 46 "Valsts policijas nolikums". Latvijas Vēstnesis, Nr. 12 (3170), 2005. g. 21. janv., 1. punkts.

7. 2010. gada 22. februāra Valsts policijas noteikumi Nr. 5 "Dienesta pienākumu izpildes darba organizācija un kontrole sabiedriskā kārtības nodrošināšanas un satiksmes uzraudzības jomā”, 2. un 4. punkts. Iegūts no: Valsts policijas iekšējā mājas lapā: http://intranet.vp.gov.lv

8. Latvijas Republikas Ekonomikas ministrijas 2014. gada jūnija ziṇojums par Latvijas tautsaimniecības attīstību. Rīga: LR Ekonomikas ministrija, 2014. ISSN 1407-4095.

Ziṇojumā norādīts, ka Latvijas ekonomika pēckrīzes periodā turpina sekmīgi attīstīties. 2012. gadā IKP pieauga par 5,2\%, bet 2013. gadā sasniedza pat 4,5\%. Preču un pakalpojumu eksporta apjomi ir sasnieguši vēsturiski augstāko līmeni, kopējam eksportam par gandrīz 20\% pārsniedzot pirmskrīzes perioda augstāko punktu. Arī turpmākā Latvijas ekonomikas izaugsme būs cieši saistīta ar eksporta iespējām un situāciju ārējos tirgos. Pakāpeniski stabilizējoties ekonomiskajai situācijai Eiropā, sagaidāms, ka turpmākajos gados Latvijas eksporta iespējas uzlabosies un ekonomikas izaugsme varētu sasniegt $4,5 \%$. 
Kristīne Kuzṇecova. Valsts un pašvaldības kompetence sabiedriskās kārtības nodrošināšanā publiskos pasākumos

9. Valsts policijas Galvenās Kärtības policijas pārvaldes darba pārskats par 2014. gadu. Nepublicēts materiāls.

10. 2012. gada 26. janvārī noslēgtais sadarbības līgums starp Latvijas Republikas Zemessardzi un Daugavpils pilsētas pašvaldību par atbalstu sabiedriskās kārtības un drošības nodrošināšanā. Nepublicēts materiāls.

11. Kuzṇecova, K. Tiecoties īstenot efektīvu sabiedriskās kārtības nodrošināšanu - Latvijas un ārvalstu pieredze. Starptautiskās zinātniski praktiskās konferences rakstu krāj. Transformācijas process tiesībās, reǵionālajā ekonomikā un ekonomiskajā politikā. Rīga: BSA, 2013. 336 lpp.

12. Kviesītis, R. Kriminālpolicija kā servisa dienests noziedzības novēršanā un apkarošanā. Valsts policijas koledžas 3. starptautiskās zinātniskās konferences rakstu krājums. 2013, 155. lpp.

13. Lijphart, A. Democracy in Plural Society. A Comparative Exproration. Yale University Press, 1977.

14. Matvejevs, A. Normatīvie akti, kas reglamentē sabiedrisko kārtību sapulču, gājienu, piketu laikā. Administratīvā un kriminālā justìcija. [LPA], Nr. 4, 2007, 59. lpp.

15. Ozolz̄ile, G. Demokrātiskās stabilitātes priekšnosacījumi. Latvijas Policijas akadēmijas raksti, 5. [sēj.]. Rìga, 1998, 41. lpp.

16. Latvijas Iekšlietu darbinieku arodbiedrības viedoklis, sk.: IeM Sabiedriskās drošības konsultatīvās padomes sēdes protokols Nr. 15, 2011. g. 24. nov. Iegūts no: http://www.iem.gov.lv/files/ text/Protokols15.pdf

17. Pieredze vardarbības novēršanā. Demonstrācijas Amsterdamā. 2014. gada 13. novembra starptautiskās konferences Globālie, reǵionālie un nacionālie mehānismi spīdzināšanas un nežēlìgas vai pazemojošas izturēšanās novēršanai: dalāmies pieredzē izdales materiāli. Nepublicēts materiāls.

18. Policing Assemblies. Amnesty International Dutch Section. Police and Human Rights Program - Short paper series No. 1. 2013, p. 14. Iegūts no: https://www.amnesty.nl/sites/ default/files/ainl_phrp_short_paper_policing_assemblies.pdf

19. Ventspils pilsētas pašvaldības 2012. un 2013. gada publiskais pārskats. Iegūts no: http:// www.ventspils.lv/lat/ventspils_parvalde/publiskie_dokumenti/pasvaldibas_publiskais_parskats/ 20. Аейпхарт, А. Многосоставные общества и демократические режимы. Полис, 1992, 217 с. 